\section{Brazilian Journal \\ of Chemical Engineering}

ISSN 0104-6632

Printed in Brazil

www.abeq.org.br/bjche

Vol. 25, No. 03, pp. 585 - 601, July - September, 2008

\title{
PERFORMANCE PREDICTION AND VALIDATION OF EQUILIBRIUM MODELING FOR GASIFICATION OF CASHEW NUT SHELL CHAR
}

\author{
M. Venkata Ramanan*, E. Lakshmanan, R. Sethumadhavan and S. Renganarayanan \\ ${ }^{1}$ Institute for Energy Studies, College of Engineering, Anna University, \\ Phone:+(91) (44) 2220-3269, Fax:+(91) (44) 2235-3637, Chennai, Tamilnadu, PIN: 600025, India. \\ E-mailvenkat@annauniv.edu, E-mail: madhavanvenkat@gmail.com \\ www.annauniv.edu
}

(Received: May 21, 2007 ; Accepted: March 15, 2008)

\begin{abstract}
Cashew nut shell, a waste product obtained during deshelling of cashew kernels, had in the past been deemed unfit as a fuel for gasification owing to its high occluded oil content. The oil, a source of natural phenol, oozes upon gasification, thereby clogging the gasifier throat, downstream equipment and associated utilities with oil, resulting in ineffective gasification and premature failure of utilities due to its corrosive characteristics. To overcome this drawback, the cashew shells were de-oiled by charring in closed chambers and were subsequently gasified in an autothermal downdraft gasifier. Equilibrium modeling was carried out to predict the producer gas composition under varying performance influencing parameters, viz., equivalence ratio (ER), reaction temperature (RT) and moisture content $(\mathrm{MC})$. The results were compared with the experimental output and are presented in this paper. The model is quite satisfactory with the experimental outcome at the ER applicable to gasification systems, i.e., 0.15 to 0.30 . The results show that the mole fraction of (i) $\mathrm{H}_{2}, \mathrm{CO}$ and $\mathrm{CH}_{4}$ decreases while $\left(\mathrm{N}_{2}+\mathrm{H}_{2} \mathrm{O}\right.$ ) and $\mathrm{CO}_{2}$ increases with $\mathrm{ER}$, (ii) $\mathrm{H}_{2}$ and $\mathrm{CO}$ increases while $\mathrm{CH}_{4},\left(\mathrm{~N}_{2}+\mathrm{H}_{2} \mathrm{O}\right)$ and $\mathrm{CO}_{2}$ decreases with reaction temperature, (iii) $\mathrm{H}_{2}, \mathrm{CH}_{4}, \mathrm{CO}_{2}$ and $\left(\mathrm{N}_{2}+\right.$ $\mathrm{H}_{2} \mathrm{O}$ ) increases while $\mathrm{CO}$ decreases with moisture content. However at an equivalence ratio less than 0.15 , the model predicts an unrealistic composition and is observed to be non valid below this ER.

Keywords: Equilibrium modeling; Gasification; Cashew shell char; Producer gas,
\end{abstract}

\section{INTRODUCTION}

Cashew (Kingdom - Plantae, Division - Magnoliophyta, Class - Magnoliopsida, Order - Sapindales, Family Anacardiaceae, Genus - Anacardium, Species - A occidentale, Binomial name - Anacardium occidentale L) (http://en.wikipedia.org/wiki/Cashew), native to eastern Brazil, was introduced into India, just as other commercial crops like rubber, coffee, tea etc. by the Portuguese nearly five centuries ago. The cashew was introduced into India in Goa, from where it spread to other parts of the country. In the beginning it was mainly considered as a crop for afforestation and soil binding to check erosion. The nuts, apple and other by- products of this crop are of commercial importance. Because of its adaptability to a wide range of agroclimatic conditions, it has become a crop of high economic value and has attained the status of an exportoriented commodity, contributing considerably to the foreign exchange earnings of the country (http://dacnet.nic.in/cashewcocoa/cashew.htm).

Presently, India is the largest producer, processor and exporter of cashews (http://www.cashewindia.org). Cultivation of cashews in India is confined mainly to the peninsular areas. It is grown in Kerala, Karnataka, Goa and Maharashtra along the west coast and Tamil Nadu, Andhra Pradesh, Orissa and West Bengal along the east coast (Agricultural

*To whom correspondence should be addressed 
Statistics Division, Ministry of Agriculture, Government of India, 2003).

The cashew tree, generally a spreading, evergreen tree, has simple, alternate, glabrous, penninerved leaves. The true fruit of the cashew tree is a kidney or boxing-glove shaped drupe that grows at the end of the pseudo-fruit. The cashew fruit (Figures 1 and 2 ) is unusual in comparison with other tree nuts since the nut is outside the fruit. The cashew apple is an edible pseudo fruit, attached to the externally born nut by a stem. In its raw state, the shell of the nut is leathery, not brittle. It contains thick vesicant oil, cashew nut shell liquid (CNSL), within a sponge-like interior. A thin skin, called the testa surrounds the kernel and separates it from the inside of the shell. The primary products of cashew nuts are the kernels which are valuable as confectionery nuts, CNSL - an important industrial raw material for resin manufacture and the shells - burnt (combusted) inefficiently for meeting thermal energy requirements.

\section{CASHEW PROCESSING}

Traditionally, extraction of the kernel from the shell of the cashew nut has been a manual operation. The nut is roasted, which makes the shell brittle and loosens the kernel from the inside of the shell. By soaking the nuts in water, the moisture content of the kernel is raised, reducing the risk of it being scorched during roasting and making it more flexible so it is less likely to crack. The CNSL is released when the nuts are roasted. The shell can be cracked either manually, using a hammer or mechanically. Manually operated blade openers are relatively inexpensive. Once the kernel is removed from the shell, it is dried, the testa is peeled off and the kernel is graded. Figure 3 gives an overview of cashew nut processing and the various choices of method.

The cashew nut shells (CNS), generated as a waste by-product, are being sold at a throw away price. Due to their low cost and abundant availability, cashew shells are utilized in an inefficient manner. These shells are burnt in a way that is generally regarded as a disposal option rather than a source of energy. The CNSL is reported to be $15-20 \%$ by weight of the unshelled nut in Africa, 25$30 \%$ by weight in India and 25\% overall (Piyali Das and Anuradda Ganesh, 2003).

\section{GASIFICATION OF CASHEW SHELL}

Owing to the rise in the cost of conventional fuel and its difficult sourcing problems, attention is now being focused towards an efficient utilization of cashew shells. Gasification is one of the effective and efficient bioenergy conversion technologies known for its modularity, turn down ratio and fuel versatility - available for harnessing this renewable bioenergy resource. Attempts have been made to convert these shells into a burnable low btu gas. However the inherent CNSL content of these shells make the gasification technology infeasible in the long run (IES, Anna University, 2006). In order to overcome the drawback posed by CNSL, the shells were charred in a chamber, thereby de-oiling them for consequent gasification. The characteristics of raw and charred cashew nut shell (charred CNS) are presented in Tables 1 and 2. The bulk density of charred CNS was measured to be $190 \mathrm{~kg} / \mathrm{m}^{3}$, indicating its amenability for gasification.

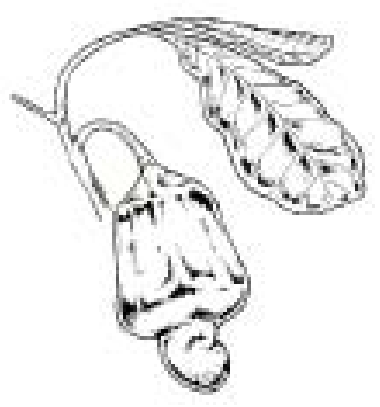

Figure 1: Cashew Fruit

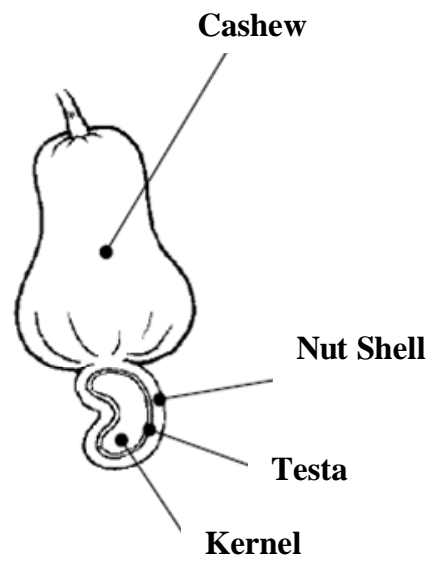

Figure 2: Cross Section of Cashew Fruit 


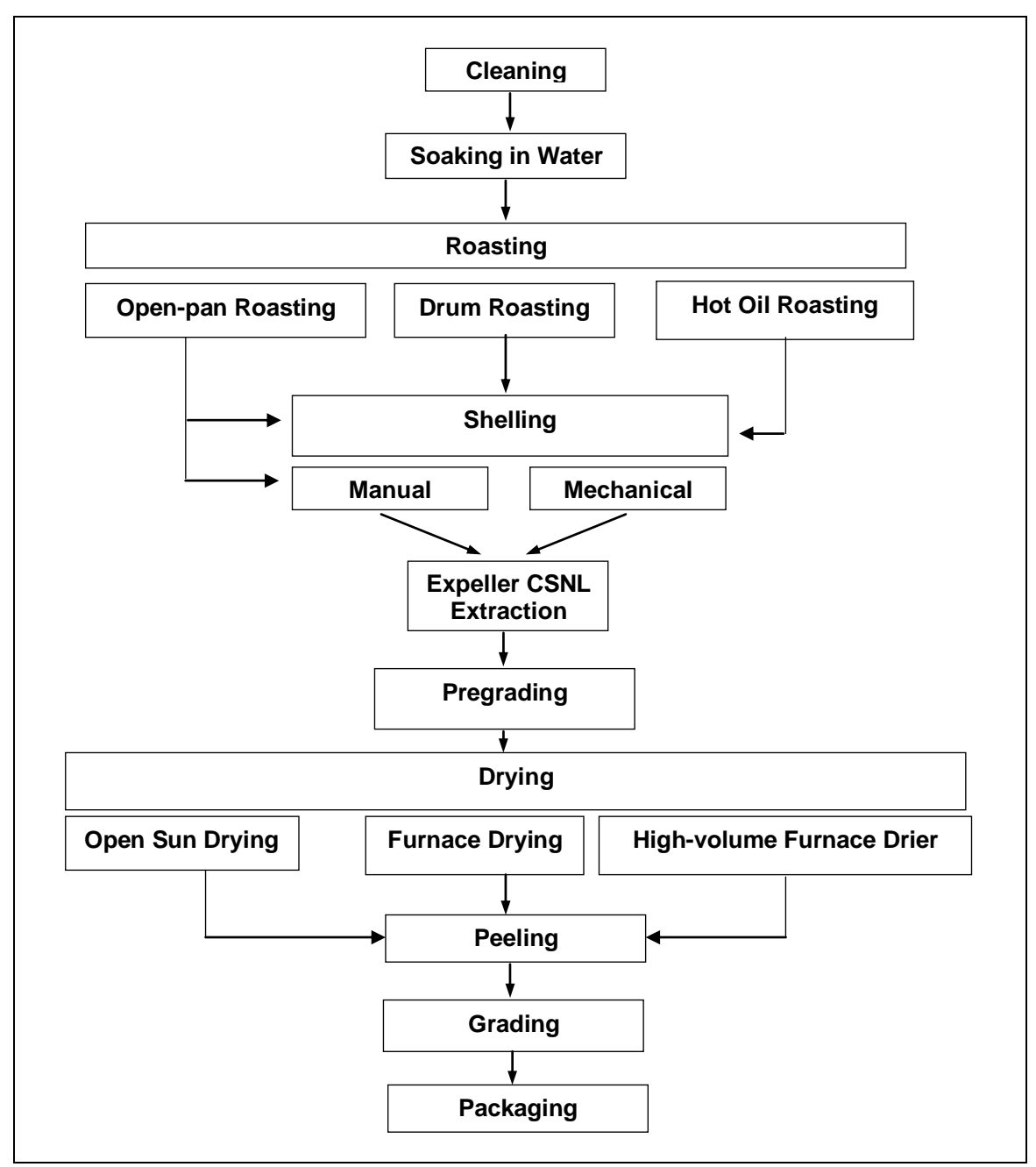

Figure 3: Cashew Processing - An Outline

Table 1: Proximate analysis of raw and charred cashew shells

\begin{tabular}{|l|c|c|}
\hline & CNS & $\begin{array}{c}\text { Charred CNS } \\
\text { (wt \% on an as-received basis) }\end{array}$ \\
\hline Moisture & (wt\% on an as-received basis) & 7 \\
Volatile Matter & 10.43 & 28 \\
Fixed Carbon & 69.31 & 59 \\
Ash & 19.26 & 6 \\
\hline
\end{tabular}

Table 2: Ultimate analysis of raw and charred cashew shells

\begin{tabular}{|l|c|c|}
\hline & CNS & $\begin{array}{c}\text { Charred CNS } \\
\text { (wt\% on an as-received basis) }\end{array}$ \\
\hline Carbon & 48.7 & 63 \\
Hydrogen & 6.96 & 3.6 \\
Nitrogen & 0.36 & 6.4 \\
Oxygen & 43.98 & 27 \\
\hline
\end{tabular}




\section{EXPERIMENTAL SETUP}

The main objective of this study was (i) to investigate the feasibility of gasification of cashew nut shells in a down-draught gasifier in the long run and (ii) to ascertain the effect of equivalence ratio (ER), moisture content (MC) and reaction temperature (RT) on gasification of cashew nut shells. Figures 4 (a), (b) and (c) depict a schematic diagram and a photograph of the experimental setup.

An induced air, closed-top, $20 \mathrm{~kW}_{\mathrm{e}}$, down-draught gasifier was chosen for the study. Provision for air entry into the gasification system was made through two inclined tuyeres, unclosed at the throat. A grate made of SS was used for holding the feedstock. The region between throat and grate functioned as a reduction zone. The hot gas generated was passed along the annuli of the reduction zone for maintenance of high reaction temperature and minimization of heat loss. A cyclone separator was placed at the gasifier outlet ahead of the ID blower to remove particulates. An aerated burner was used for flaring the producer gas generated. The whole gasifier assembly was mounted on a toughened helical spring, enabling it to vibrate to ensure a smooth fuel flow. A poking rod was fixed at the bottom and linked to the grate. Pushing and pulling the poking rod created an impact on the grate, thereby disintegrating and discharging any clogged residual particles into the ash box. Provisions were made for measuring the temperature, pressure and gas composition at appropriate location in the gasifier. A stand with a ladder arrangement was used for feeding the raw material in at the fuel feed port.

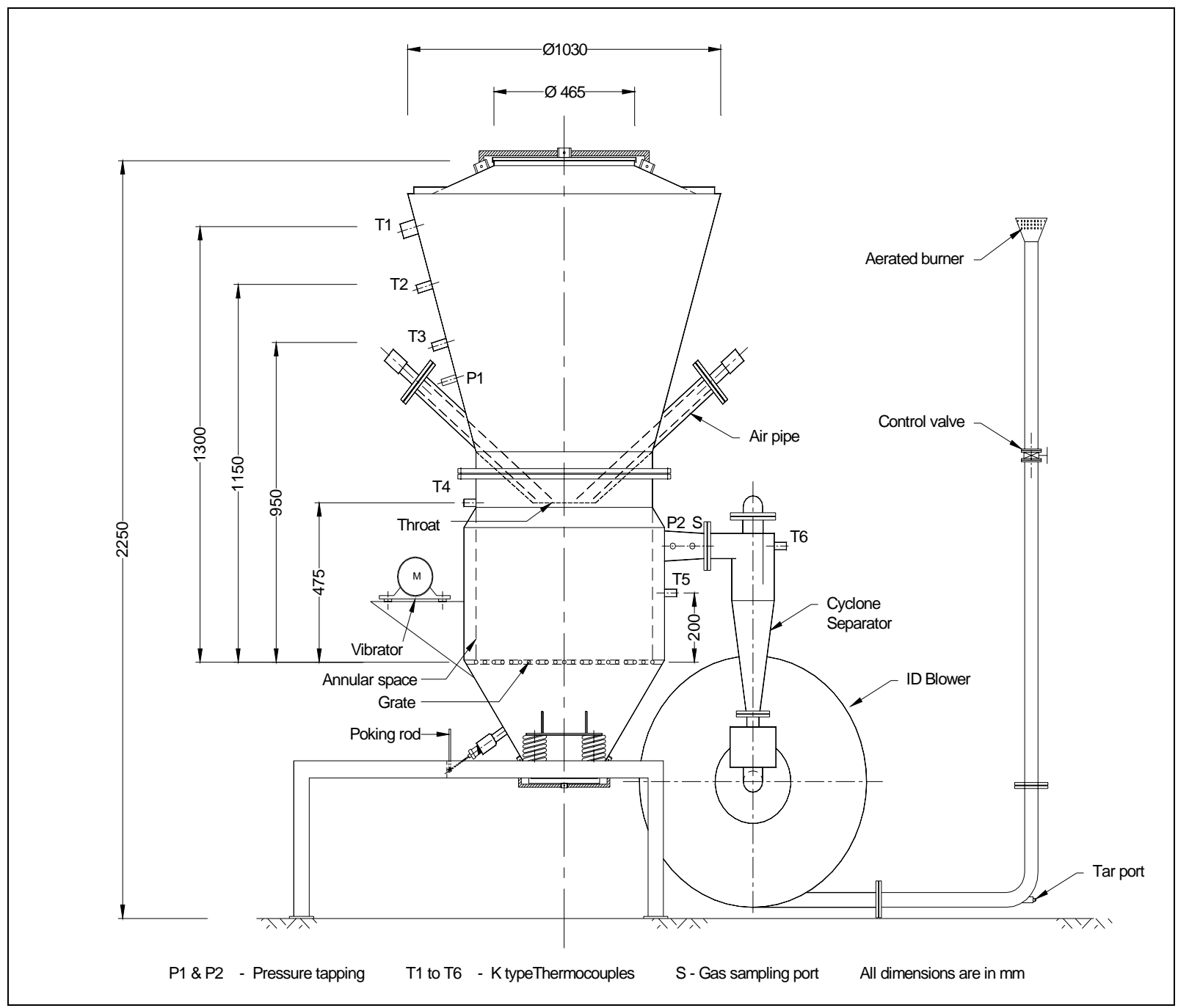

Figure 4(a): Schematic diagram of Gasifier 


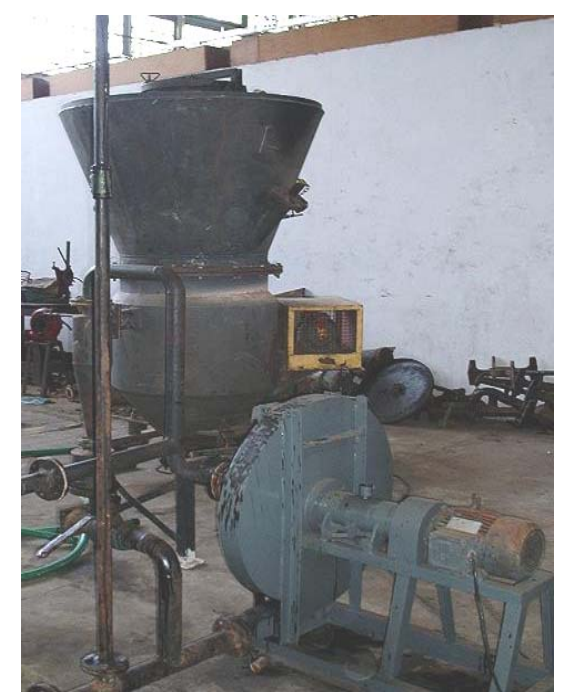

Figure 4(b): Photograph of experimental setup

\section{PROCESS INSTRUMENTATION AND CONTROL}

The base fuel characteristics were established with a proximate analyzer (muffle furnace + micro weighing balance with associated auxiliaries). The parameters studied included moisture content (ASTM D 3173-73), volatile matter (ASTM D 317573) and ash content (ASTM D 3174-73). The remainder was fixed carbon (FC). The calorific value of cashew shell was established using a standardized (benzoic acid-based) bomb calorimeter and the result was observed to match well the correlations framed for estimation of calorific value for biofuels (Parikh et al. 2005). A Junkers gas calorimeter was used for determining the calorific value of producer gas. Producer gas composition was analyzed using a Siemens Oxymat 61 online gas analyzer (which estimates $\mathrm{O}_{2}$ using the paramagnetic principle), Ultramat 23 (which estimates $\mathrm{CO}, \mathrm{CO}_{2}$ and $\mathrm{CH}_{4}$ using nondispersive infrared multilayer technology) and Calomat 61 (which estimates $\mathrm{H}_{2}$ using the thermal conductivity principle). Details regarding the producer gas composition were recorded on the PC every second using Siprom-GA software. The gas sampling system consisted of a wash bottle, a condensation pot, a coalescence filter, a suction pump, a fine filter, a flame arrestor and a diaphragm pump. Chromel-Alumel (K-type) thermocouples were used for measuring the temperature in different zones ( $\mathrm{T} 1$ to $\mathrm{T} 6$ ). Thermocouples were fixed permanently and measured continuously in all zones except at the throat (T4). For temperature measurement at the throat, a flexible K-type

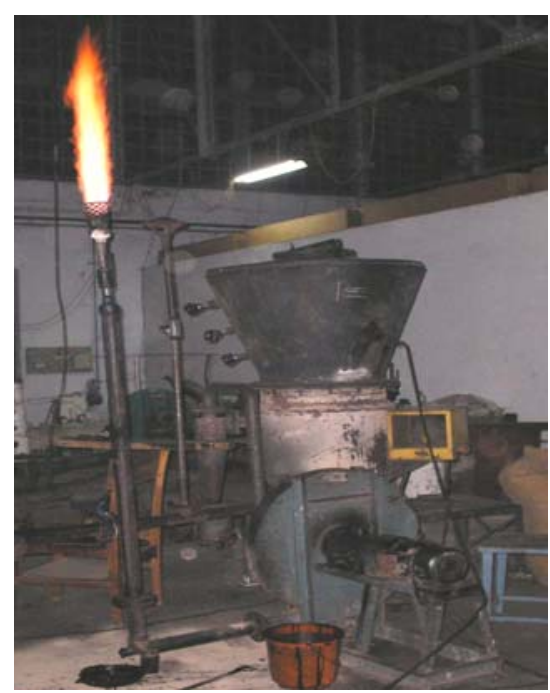

Figure 4(c): Gasification of CNSC

thermocouple was inserted along the air port at regular intervals. Temperatures from different zones were logged simultaneously using an Agilent (34907 A) data acquisition system. The surface temperature of the gasifier was measured with a Kane infrared thermometer (UEI-INF 200). An Airflow thermoanemometer (TA 35) was used for measuring the air flow to the gasifier. A calibrated S-type Pitot Tube \& Comark digital manometer was employed for establishing the producer gas flow. The air entry into the system, and thus the ER, is controlled by a globe valve placed at the discharge end of the blower. Water-filled U-tube manometers were deployed for measuring the pressure buildup across the gasifier bed.

\section{EXPERIMENTAL PROCEDURE}

Preweighed batches of CNSC, each weighing approx $25 \mathrm{kgs}$, were placed near the system for hassle- free operation during fuel loading. Gasification of CNSC was initiated by keeping the gas valve open, followed by operation of the ID blower and holding a flame near the air tuyere. The flame was sucked into the system due to the draught created by the blower. Within three minutes, flue gas was observed at the flare port. Normally after 5 to 10 minutes, the onset of gasification commenced and producer gas emanated from the flare port. Experimental analysis was started once the system become stabilized. Generally it took 60 to $90 \mathrm{~min}$ to achieve stabilization, which was ensured by inferring a constant temperature in the raw gas and the 
reduction zone. The fuel consumption rate was measured by recharging the gasifier on an hourly basis and filling the gasifier volume to a predetermined level at the top of the gasifier hopper. The ash door was operated at regular intervals to remove the ash that had accumulated on the grate.

The major influential parameters in the performance of gasification system are equivalence ratio, the bed temperature and moisture content of the feed stock. Equivalence ratio was varied by adjusting the air supplied to the gasifier bed. Since, the gasifier used was autothermal, the option of maintaining constant bed temperature for varying equivalence ratio/moisture content was ruled out. The experiments were conducted in various permutations and combinations and the outcomes are compared with the modeled results.

\section{EQUILIBRIUM MODELING}

The typical chemical formula of CNS char, based on a single atom of carbon, is observed to be $\mathrm{CH}_{0.686} \mathrm{O}_{0.32}$. Equilibrium modeling was carried out, based on this formula, for predicting its gasification characteristics.

The following assumptions are made in the modeling approach:

- The ideal gas laws are valid.

- All reactions are at thermodynamic equilibrium.

- Gases are in equilibrium during flow through the char bed.

- The pressure in the char bed is atmospheric and constant.

- Reactions proceed adiabatically.

- Nitrogen present in both fuel and air is inert.

- Ash is inert and is not involved in any of the reactions, either as a chemical species or as a catalyst.

- No radial temperature gradients/concentrations exist.

- No gas is accumulated in the char bed.

- There is no resistance to conduction of heat and diffusion of mass inside the char particles.

- There is no tar in the gasification zone.

- Carbon conversion efficiency is $100 \%$

- Producer gas comprises only $\mathrm{CO}_{2}, \mathrm{CO}, \mathrm{H}_{2}, \mathrm{CH}_{4}$, $\mathrm{N}_{2}$ and $\mathrm{H}_{2} \mathrm{O}$.

Based on the above assumptions, the global reaction of CNS char with air could be written as

$$
\begin{aligned}
& \mathrm{CH}_{0.686} \mathrm{O}_{0.32}+\mathrm{w} \mathrm{H}_{2} \mathrm{O}+\mathrm{m} \mathrm{O}_{2}+3.76 \mathrm{~m} \mathrm{~N}_{2}=\mathrm{x}_{1} \mathrm{H}_{2}+ \\
& \mathrm{x}_{2} \mathrm{CO}+\mathrm{x}_{3} \mathrm{CO}_{2}+\mathrm{x}_{4} \mathrm{H}_{2} \mathrm{O}+\mathrm{x}_{5} \mathrm{CH}_{4}+3.76 \mathrm{~m} \mathrm{~N}_{2}
\end{aligned}
$$

The above reaction represents an overall reaction, but a number of competing intermediate reactions take place during the process, of which the following are predominant:

Oxidation

$\mathrm{C}+\mathrm{O}_{2}=\mathrm{CO}_{2} \quad(-393.8 \mathrm{~kJ} / \mathrm{mol})$

Steam gasification

$\mathrm{C}+\mathrm{H}_{2} \mathrm{O}=\mathrm{CO}+\mathrm{H}_{2} \quad(+131.4 \mathrm{~kJ} / \mathrm{mol})$

Boudouard reaction

$\mathrm{C}+\mathrm{CO}_{2}=2 \mathrm{CO} \quad(+172.6 \mathrm{~kJ} / \mathrm{mol})$

Methanation reaction

$\mathrm{C}+2 \mathrm{H}_{2}=\mathrm{CH}_{4} \quad(-74.9 \mathrm{~kJ} / \mathrm{mol})$

Water gas shift reaction

$\mathrm{CO}+\mathrm{H}_{2} \mathrm{O}=\mathrm{CO}_{2}+\mathrm{H}_{2} \quad(-41.2 \mathrm{~kJ} / \mathrm{mol})$

Of these, only four reactions are independent, the oxidation, steam gasification, Boudouard and methanation reactions. The water gas shift reaction can be considered as the subtraction of the steam gasification and Boudouard reactions. According to Von Fredersdorff and Elliot (1963) the oxidation reaction is typically assumed to be very fast and is completed quickly, while the other three reactions, namely boudouard, steam gasification and methanation, are in equilibrium. As observed, the water gas shift reaction is a combination of the boudouard and steam gasification reactions. Hence, the water gas shift and methanation reaction could be considered to be in equilibrium.

The equilibrium constants for the methanation and water gas shift reactions [Eq. (5)] are

$$
\begin{aligned}
\mathrm{K}_{1} & =\frac{\left[\mathrm{P}_{\mathrm{CH}_{4}}\right]}{\left[\mathrm{p}_{\mathrm{H}_{2}}\right]^{2}} \\
\mathrm{~K}_{2} & =\frac{\left[\mathrm{P}_{\mathrm{CO}_{2}}\right] \cdot\left[\mathrm{P}_{\mathrm{H}_{2}}\right]}{\left[\mathrm{P}_{\mathrm{CO}}\right] \cdot\left[\mathrm{P}_{\mathrm{H}_{2}} \mathrm{O}\right]}
\end{aligned}
$$

In the global reaction [Eq. (1)], there are six unknowns, $\mathrm{x}_{1}, \mathrm{x}_{2}, \mathrm{x}_{3}, \mathrm{x}_{4}, \mathrm{x}_{5}$ and $\mathrm{m}$, representing the 
molar composition of five unknown species in the producer gas and the oxygen content for the reaction. Hence, to predict the constituents of producer gas, a set of six equations, formulated by balancing the different constituents involved in the global reaction, is required.

Carbon balancing

$1=X_{2}+X_{3}+X_{5}$

Hydrogen balancing

$2 \mathrm{w}+0.6847=2 \mathrm{X}_{1}+2 \mathrm{X}_{4}+4 \mathrm{X}_{5}$

Oxygen balancing

$\mathrm{w}+0.3217+2 \mathrm{~m}=\mathrm{X}_{2}+2 \mathrm{X}_{3}+\mathrm{X}_{4}$

Equilibrium constant from methanation [Eq. (5)]

$\mathrm{K}_{1}=\frac{\mathrm{X}_{5}}{\left(\mathrm{X}_{1}\right)^{2}}$

Equilibrium constant from the shift reaction [Eq. (8)]

$\mathrm{K}_{2}=\frac{\left(\mathrm{X}_{3}\right)\left(\mathrm{X}_{1}\right)}{\left(\mathrm{X}_{2}\right)\left(\mathrm{X}_{4}\right)}$

$\mathrm{MC}=\frac{\text { mass of water }}{\text { mass of wet biomass }} \times 100 \%$

$\mathrm{MC}=\frac{18 \mathrm{w}}{17.80+18 \mathrm{w}} \times 100 \%$

When moisture content is known, the value of w is a constant.

The reaction process is assumed to be adiabatic, and hence heat balancing of the reactants and products of the global reaction results in the equation shown:

$$
\begin{aligned}
& \mathrm{H}_{\mathrm{f}_{\mathrm{CNSC}}^{\circ}}^{\circ}+\mathrm{w}\left(\mathrm{H}_{\mathrm{fH}_{2} \mathrm{O}(1)}^{\circ}+\mathrm{H}_{(\mathrm{vap})}\right)+ \\
& \mathrm{m}_{\mathrm{f}_{\mathrm{O}_{2}}}^{\circ}+3.76 \mathrm{~m} \mathrm{H}_{\mathrm{f}_{\mathrm{N}_{2}}}^{\circ}= \\
& \mathrm{X}_{1} \mathrm{H}_{\mathrm{f}_{\mathrm{H}_{2}}}^{\circ}+\mathrm{X}_{2} \mathrm{H}_{\mathrm{f}_{\mathrm{CO}}}^{\circ}+\mathrm{X}_{3} \mathrm{H}_{\mathrm{f}_{\mathrm{CO}_{2}}}+\mathrm{X}_{4} \mathrm{H}_{\mathrm{f}_{\mathrm{H}_{2} \mathrm{O}}^{\circ}} \\
& +\mathrm{X}_{5} \mathrm{H}_{\mathrm{f}_{\mathrm{CH}_{4}}}^{\circ}+\Delta \mathrm{T}\left(\mathrm{X}_{1} \mathrm{C}_{\mathrm{p}_{\mathrm{H}_{2}}}+\mathrm{X}_{2} \mathrm{C}_{\mathrm{p}_{\mathrm{CO}}}\right) \\
& \left.\mathrm{X}_{3} \mathrm{C}_{\mathrm{p}_{\mathrm{CO}_{2}}}+\mathrm{X}_{4} \mathrm{C}_{\mathrm{p}_{\mathrm{H}_{2} \mathrm{O}}}+\mathrm{X}_{5} \mathrm{C}_{\mathrm{p}_{\mathrm{CH}_{4}}}+3.76 \mathrm{mC}_{\mathrm{p}_{\mathrm{N}_{2}}}\right)
\end{aligned}
$$

The heating value of the fuel $\left(\mathrm{H}^{\circ}{ }_{\mathrm{f}_{\mathrm{CNSC}}}\right)$ was determined experimentally with a bomb calorimeter. The heat of formation of the various gases could be sourced from the JANAF thermochemical tables (Stull and Prophet, 1971) and the $\Delta H^{\circ}$ for the gases constituting the present study are presented in Table 3.

The dependence of specific heat on temperature is given by various empirical equations and the most simplified version (Robert and Don, 1984) is

$$
\begin{aligned}
& \mathrm{C}_{\mathrm{P}_{\mathrm{am}}}=\mathrm{R}\left[\mathrm{A}+\mathrm{BT}_{\mathrm{am}}+\right. \\
& \left.\frac{\mathrm{C}}{3}\left(4 \mathrm{~T}^{2} \mathrm{am}-\mathrm{T}_{1} \mathrm{~T}_{2}\right)+\frac{\mathrm{D}}{\mathrm{T}_{1} \mathrm{~T}_{2}}\right]
\end{aligned}
$$

The values of the heat capacity constants, applicable to our equations, are shown in Table 4.

The equilibrium constant $\mathrm{K}$ is a function of temperature and could be equated as (Zainal et al. 2001)

$-\mathrm{RT} \ln \mathrm{K}=\Delta \mathrm{G}^{\circ}$

$\frac{\mathrm{d} \ln \mathrm{K}}{\mathrm{dT}}=\frac{\Delta \mathrm{H}^{\circ}}{\mathrm{RT}^{2}}$

The values of standard Gibbs function of formation for various gas compositions involved are shown in Table 5 (Stull and Prophet, 1971)

Heat of formation is basically a function of temperature, and hence Eq. (19) can be integrated as follows (Zainal et al. 2001):

$\ln \mathrm{K}=\int \frac{\Delta \mathrm{H}^{\circ}}{\mathrm{RT}^{2}} \mathrm{dT}+\mathrm{I}$

$\Delta \mathrm{H}^{\circ}$ could also be equated as (Robert and Don, 1984)

$$
\begin{aligned}
& \frac{\Delta \mathrm{H}^{\circ}}{\mathrm{R}}=\frac{\mathrm{J}}{\mathrm{R}}+(\Delta \mathrm{A}) \mathrm{T}+ \\
& \frac{\Delta \mathrm{B}}{2} \mathrm{~T}^{2}+\frac{\Delta \mathrm{C}}{3} \mathrm{~T}^{3}-\frac{\Delta \mathrm{D}}{\mathrm{T}}
\end{aligned}
$$

Substituting Eq. (21) into Eq. (20)

$$
\begin{aligned}
& \ln \mathrm{K}=-\frac{\mathrm{J}}{\mathrm{RT}}+\Delta \mathrm{A} \ln \mathrm{T}+ \\
& \frac{\Delta \mathrm{B}}{2} \mathrm{~T}+\frac{\Delta \mathrm{C}}{6} \mathrm{~T}^{2}+\frac{\Delta \mathrm{D}}{2 \mathrm{~T}^{2}}+\mathrm{I}
\end{aligned}
$$


The dependence of $\Delta \mathrm{G}^{\circ}$ on temperature can be analyzed as

$$
\begin{aligned}
& \Delta \mathrm{G}=\mathrm{J}-\mathrm{RT}(\Delta \mathrm{A} \ln \mathrm{T}+ \\
& \left.\frac{\Delta \mathrm{B}}{2} \mathrm{~T}+\frac{\Delta \mathrm{C}}{6} \mathrm{~T}^{2}+\frac{\Delta \mathrm{D}}{2 \mathrm{~T}^{2}}+\mathrm{I}\right)
\end{aligned}
$$

Both $\mathrm{J}$ and $\mathrm{I}$ are respectively calculated from Eq. 21 and Eq. 23 at temperature 298.15 K.

Two equilibrium equations are required to determine the equilibrium constants $\mathrm{K}_{1}$ and $\mathrm{K}_{2} . \mathrm{K}_{1}$ is the equilibrium constant for the reaction in Eqn. (5) and is solved as follows:

$\mathrm{C}+2 \mathrm{H}_{2}=\mathrm{CH}_{4}$

$\Delta=\mathrm{CH}_{4}-\mathrm{C}-2 \mathrm{H}_{2}$

$\Delta \mathrm{A}, \Delta \mathrm{B}, \Delta \mathrm{C}$ and $\Delta \mathrm{D}$ can be obtained from the data on heat capacity.
The equations to determine the values of $\Delta \mathrm{A}, \Delta \mathrm{B}$, $\Delta \mathrm{C}$ and $\Delta \mathrm{D}$ can be expressed as

$$
\begin{aligned}
& \Delta \mathrm{A}=\mathrm{A}_{\mathrm{CH} 4}-\mathrm{A}_{\mathrm{C}}-2 \mathrm{~A}_{\mathrm{H} 2} \\
& \Delta \mathrm{B}=\mathrm{B}_{\mathrm{CH} 4}-\mathrm{B}_{\mathrm{C}}-2 \mathrm{~B}_{\mathrm{H} 2} \\
& \Delta \mathrm{C}=\mathrm{C}_{\mathrm{CH} 4}-\mathrm{C}_{\mathrm{C}}-2 \mathrm{C}_{\mathrm{H} 2} \\
& \Delta \mathrm{D}=\mathrm{D}_{\mathrm{CH} 4}-\mathrm{D}_{\mathrm{C}}-2 \mathrm{D}_{\mathrm{H} 2}
\end{aligned}
$$

Application of these equations reveals the equilibrium constants for $\mathrm{K}_{1}$.

Similarly $K_{2}$ is the equilibrium constant for the water gas shift reaction (Eq. 6) and could be solved by adopting the same procedure. Figure 5 depicts the calculation procedure for the equilibrium model in a concise fashion.

The molar concentration of individual species could be predicted by using $\mathrm{K}_{1}$ and $\mathrm{K}_{2}$ and solving equations 9 to 16 .

Table 3: Heat of formation at 298.15 K (Stull and Prophet, 1971)

\begin{tabular}{|l|c|c|}
\hline Chemical Species & Phase & $\Delta \mathbf{H}^{\circ}{ }_{\text {f298 }}$ \\
\hline Water & $\mathrm{g}$ & -241818 \\
Water & $\mathrm{g}$ & -285830 \\
Carbon dioxide & $\mathrm{g}$ & -393509 \\
Carbon monoxide & $\mathrm{g}$ & -110525 \\
Methane & $\mathrm{g}$ & -74520 \\
Hydrogen & $\mathrm{g}$ & 0 \\
Oxygen & $\mathrm{g}$ & 0 \\
Nitrogen & $\mathrm{g}$ & 0 \\
\hline
\end{tabular}

Table 4: Heat Capacities for constants A, B, C and D (Robert and Don, 1984)

\begin{tabular}{|l|c|c|c|c|r|}
\hline Chemical Species & $\mathbf{T}_{\max }$ & $\mathbf{A}$ & $\mathbf{1 0}^{\mathbf{3}} \mathbf{B}$ & $\mathbf{1 0}^{\mathbf{6}} \mathbf{C}$ & $\mathbf{1 0}^{-5} \mathbf{D}$ \\
\hline Methane & 1500 & 1.702 & 9.081 & -2.164 & - \\
Hydrogen & 3000 & 3.249 & 0.422 & - & 0.083 \\
Carbon monoxide & 2500 & 3.376 & 0.557 & - & -0.031 \\
Carbon dioxide & 2000 & 5.457 & 1.047 & - & -1.157 \\
Nitrogen & 2000 & 3.280 & 0.593 & - & 0.040 \\
Water & 2000 & 3.470 & 1.450 & - & 0.121 \\
Carbon & 2000 & 1.771 & 0.771 & & -0.867 \\
\hline
\end{tabular}

Table 5: Gibbs functions of formation at 298.15 K (Stull and Prophet, 1971)

\begin{tabular}{|l|c|c|}
\hline Chemical Species & Phase & $\Delta_{\mathbf{G}^{\circ}{ }_{\text {2298 }}}$ \\
\hline Water & $\mathrm{g}$ & -228572 \\
Water & 1 & -237129 \\
Carbon dioxide & $\mathrm{g}$ & -394359 \\
Carbon monoxide & $\mathrm{g}$ & -137169 \\
Methane & $\mathrm{g}$ & -50460 \\
Hydrogen & $\mathrm{g}$ & 0 \\
Oxygen & $\mathrm{g}$ & 0 \\
Nitrogen & $\mathrm{g}$ & 0 \\
\hline
\end{tabular}




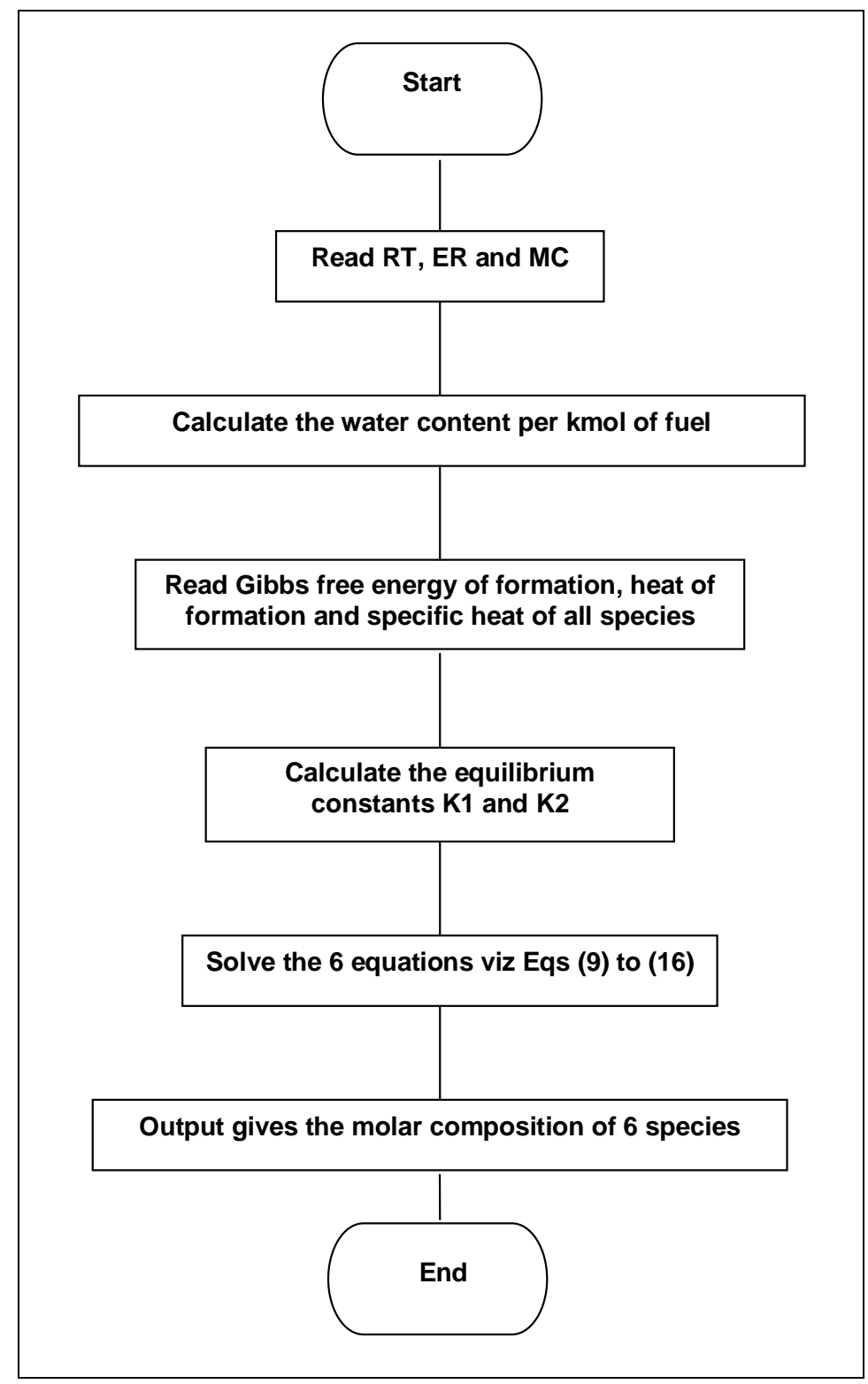

Figure 5: Flow chart for calculation of equilibrium constant

\section{RESULTS AND DISCUSSIONS}

\section{Effect of Equivalence Ratio on Molar Concentration}

Equivalence ratio (ER) is the ratio of the actual $\mathrm{A} / \mathrm{F}$ ratio to the stoichiometric $\mathrm{A} / \mathrm{F}$ ratio. Discarding the fuel component, it could also be defined as the ratio of actual air supplied to the stoichiometric air requirement. For an ideal combustion, the value of ER is 1, while in practical cases it is always greater than 1 , being governed predominantly by the type of fuel being combusted. For gasifiers, the value of ER would range from 0.15 to 0.4 . In the process of autothermal gasification, part of fuel is burnt to release energy to sustain the endothermic gasification reactions. The lower limit of ER in an autothermal gasifier is fixed by considering a variety of factors like the minimum quantity of air required to burn part of the fuel to release energy for supporting endothermic reactions, required carbon conversion efficiency, the fixed loss of heat that needs to be accounted for in maintaining the reactor temperature etc., Similarly, the upper limit of ER is fixed by factors like tar quantity, gas quality, reactor temperature and ash fusion point.

The effect of ER on gasification of CNSC at a fixed moisture of $7 \%$ and at a reaction temperature of $1373 \mathrm{~K}$ is depicted in Figs 6 to 10. 


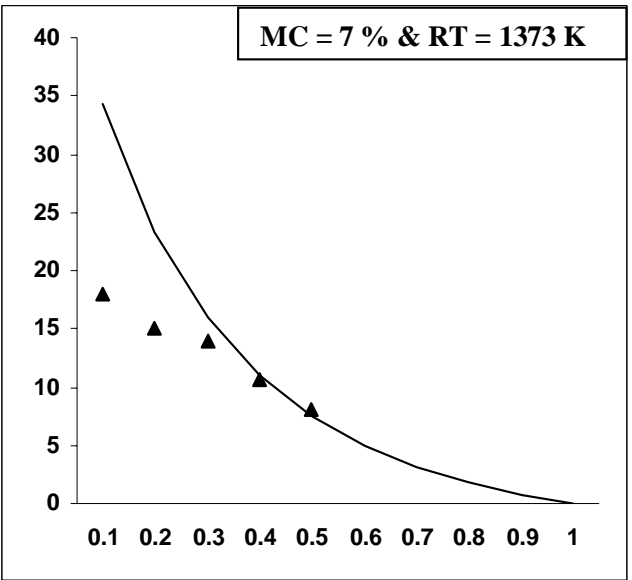

Figure 6: Molar \% of $\mathrm{H}_{2}$ vs ER

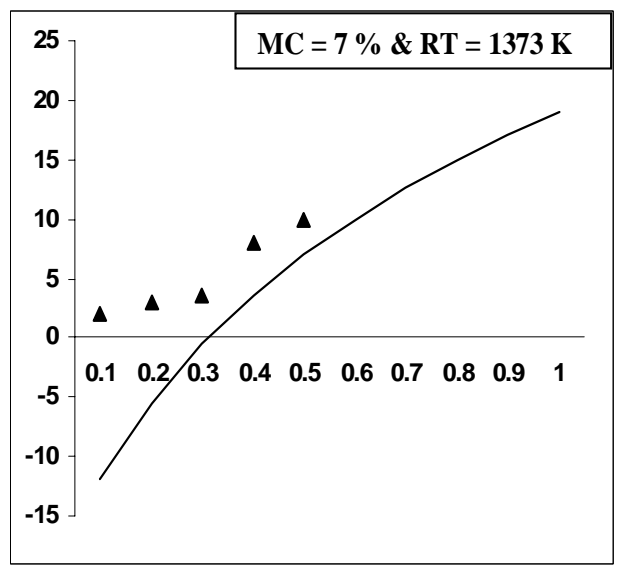

Figure 8: Molar \% of $\mathrm{CO}_{2}$ vs ER

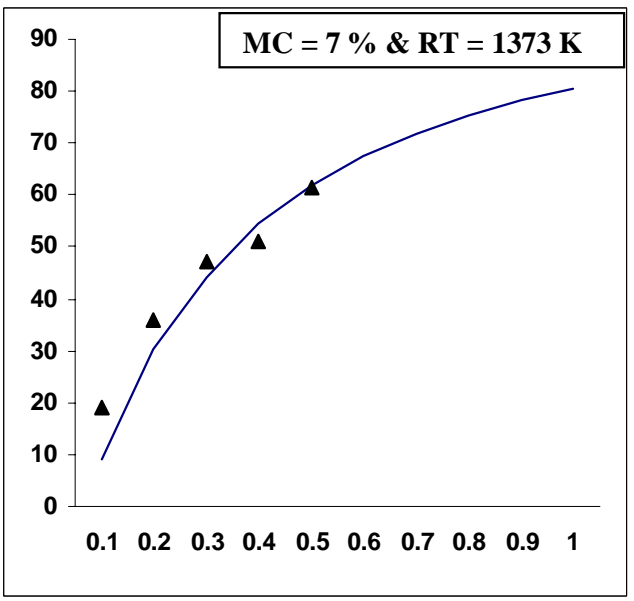

Figure 10: Molar \% of $\mathrm{N}_{2}+\mathrm{H}_{2} \mathrm{O}$ vs ER

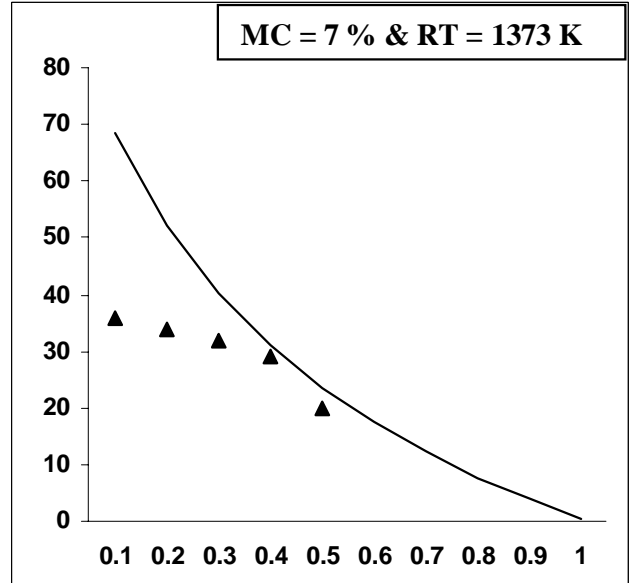

Figure 7: Molar \% of COvs ER

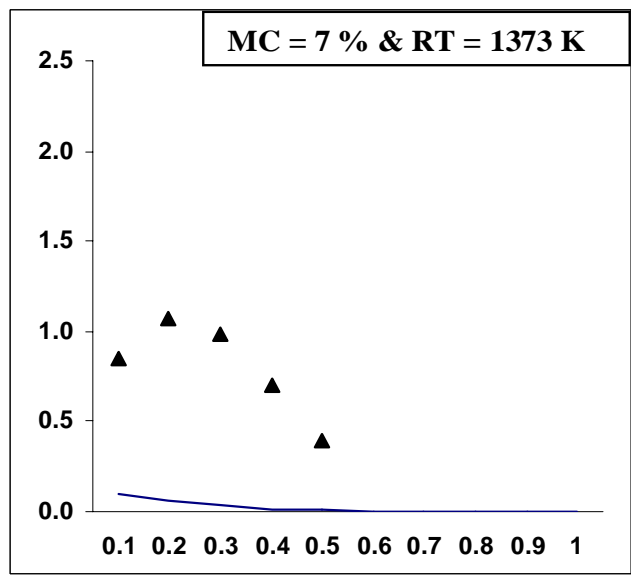

Figure 9: Molar \% of $\mathrm{CH}_{4}$ vs ER

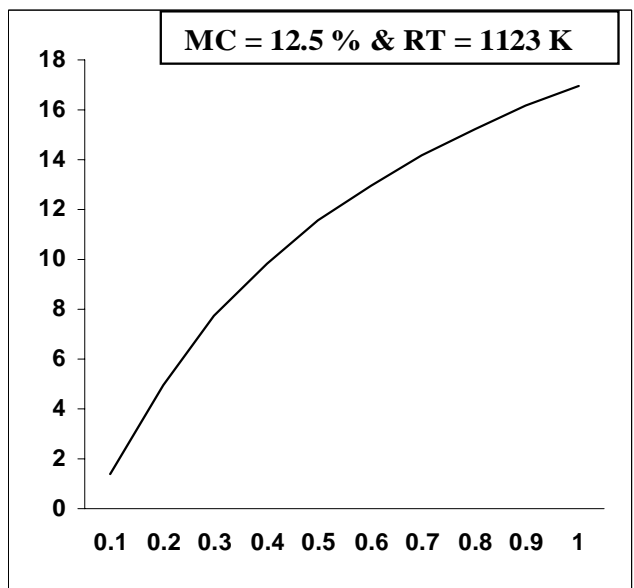

Figure 11: Molar \% of CO2 vs ER Fuel: Casuarina Wood 


\section{a) Effect of ER on Hydrogen and CO}

The yield of hydrogen from the model is observed to follow a decreasing trend with increasing ER. A similar trend is reported by other researchers like Turn et al. (1998). The trend is quite misleading at first sight. It is a common reality that as the ER increases, the temperature of the any oxidation reaction is bound to increase. This trend is applicable only to allothermal systems, where the temperature of the gasifier is controlled externally (McKendry, 2002). In equilibrium modeling, it is assumed that temperature is maintained constant even at different ERs. However for autothermal systems, the increase in ER would have two paradoxical phases, one following the other in a sequential manner. When the ER is increased from low values, the temperature of the system increases, resulting in a marked increase in generation of both gas and its $\mathrm{H}_{2}$ concentration - phase 1 . However beyond a governing limit, the oxidation reaction predominates due to availability of excess oxygen and the yield of $\mathrm{H}_{2}$ drops for conversion of $\mathrm{H}_{2}$ to $\mathrm{H}_{2} \mathrm{O}$ - phase 2. The typical ER reported by Lv et al. (2004) is 0.19 to 0.23 for phase 1 and 0.23 to 0.27 for phase 2. The gasifier adopted for experimenting gasification of CNSC is autothermal. Hence, the bed reaction temperatures varied with different ERs. The model predicts unreasonably high $\mathrm{H}_{2}$ at lower ERs. Ruggiero and Manfrida (1999) described the irrelevance of equilibrium models, which assume perfect gas behavior for very low ERs as these models cannot describe pyrolysis processes due to the presence of liquid hydrocarbons as pyrolysis products. Desrosiers (1981) predicted thermodynamic ER for gasification of dry wood as 0.28 . Considering the range of $\mathrm{H}_{2}$ yield, as predicted by the model with experimental values in the ER range of 0.25 to 0.35 , the model values compare quite reasonable with the experimented values. At an ER of 1 , the $\mathrm{H}_{2}$ is null, indicating the complete combustion and conversion of all $\mathrm{H}_{2}$ to water vapor. The prevailing conditions and criteria quoted for $\mathrm{H}_{2}$ are equally applicable for $\mathrm{CO}$, albeit at a different magnitude.

\section{b) Effect of ER on $\mathrm{CO}_{2}$ and $\mathrm{CH}_{4}$}

The molar percentage of $\mathrm{CO}_{2}$ is observed to increase with an increase in ER, similar to the trend established by Altafini et al. (2003). In reality, the trend of $\mathrm{CO}_{2}$ could be correlated with the trend opposite to that for $\mathrm{CO}$. A decrease in concentration of $\mathrm{CO}_{2}$ indicates better gasification efficiency (Zainal et al. 2002). The modeled results for charred CNS indicated negative values of $\mathrm{CO}_{2}$ at lower ERs, which is quite unrealistic. Ruggiero and Manfrida's (1999) statement could be applied to this condition also. However, after a critical analysis of the modeling, it was decided to check the trend of $\mathrm{CO}_{2}$ for other established fuels, for which modeling results had already been reported. Accordingly, the devised model was applied to casuarina wood $\left(\mathrm{CH}_{1.44} \mathrm{O}_{0.65}\right)$, whose proximate and ultimate analyses are listed in Tables 6 and 7. The trend of $\mathrm{CO}_{2}$ for casuarina wood is observed to be increasing and positive for all ERs (Fig. 11). Other constituents of the global reaction [Eq.1] remain the same, the $\mathrm{C} / \mathrm{H}$ and $\mathrm{C} / \mathrm{O}$ ratios of charred $\mathrm{CNS}$ are observed to be 2.18 and 2.08 times greater than the $\mathrm{C} / \mathrm{H}$ and $\mathrm{C} / \mathrm{O}$ ratios of casuarina. Hence it was inferred that the $\mathrm{C} / \mathrm{H}$ ratio to some extent affects the model output at lower ERs. This was confirmed by increasing the $\mathrm{H} / \mathrm{C}$ ratio on the reactant side in the global reaction [Eq.1] by increasing the fuel moisture content and analyzing the molar percentage of $\mathrm{CO}_{2}$ at different ERs. At a moisture level of $40 \%$, the $\mathrm{CO}_{2}$ yields are all observed to be positive (Fig. 20), indicating the effect of $\mathrm{C} / \mathrm{H}$ ratio on modeling at lower ERs. Though the values depicted by the model at lower ERs per se would not be relevant to gasification, the cause for it had been reported. It was found that the model predicts well the $\mathrm{CO}_{2}$ concentration at higher ERs and that pertaining to gasification.

Table 6: Proximate analysis of casuarina wood

\begin{tabular}{|l|c|}
\hline & (wt\% on an as-received basis) \\
\hline Moisture & 12.5 \\
Volatile Matter & 67.5 \\
Fixed Carbon & 18 \\
Ash & 2 \\
\hline
\end{tabular}

Table 7: Ultimate analysis of casuarina wood

\begin{tabular}{|l|c|}
\hline & (wt\% on an as-received basis) \\
\hline Carbon & 48.5 \\
Hydrogen & 6.06 \\
Oxygen & 43.3 \\
Nitrogen & 2.14 \\
\hline
\end{tabular}

Brazilian Journal of Chemical Engineering Vol. 25, No. 03, pp. 585 - 601, July-September, 2008 
Mansaray et al. (1999) inferred that increasing the ER results in a decrease in concentrations of methane and other light hydrocarbons, which have relatively high heating values. The model results validate the claim that $\mathrm{CH}_{4}$ concentration decreases with increasing ER. Conversely, the prediction on $\mathrm{CH}_{4}$ made by the model is lower than the actual ones by a large margin. Pellegrini and Oliveira Jr. (2007) experienced similar differences in $\mathrm{CH}_{4}$ predicted by the model and experiment and referred to the cause as a result of the sudden cessation of gasification reactions at the bottom of the reactor. This cessation is a consequence of the temperatures at the bottom, which are too low to start up the reactions. In an equilibrium model, it is assumed that all reactions achieve a steady-state condition; thus no kinetic effects (such as sudden cessation) are considered. To overcome the differences in mole fractions, a fixed $\mathrm{CH}_{4}$ molar correction needs to be adopted, as reported by Fock and Thomsen (2000).

\section{c) Effect of ER on $\mathrm{N}_{2}$ and $\mathrm{H}_{2} \mathrm{O}$}

Gas analysis was not carried out on a dry basis for want of facilities. Hence the remainder of the measured components, viz., $\mathrm{CO}, \mathrm{CO}_{2}, \mathrm{H}_{2}, \mathrm{O}_{2}$ and $\mathrm{CH}_{4}$ is assumed to be mix of $\mathrm{N}_{2}$ and $\mathrm{H}_{2} \mathrm{O}$. The devised model predicted the yield of $\mathrm{N}_{2}$ and $\mathrm{H}_{2} \mathrm{O}$ individually and the molar concentrations of these constituents were combined as a mix to compare with the experimental values. Generally nitrogen formation could be attributed to the $\mathrm{N}_{2}$ from fuel and $\mathrm{N}_{2}$ from air. With the nitrogen in fuel remaining constant, the increase in ER increases the $\mathrm{N}_{2}$ supplied to the system, and hence the higher yield of $\mathrm{N}_{2}$ at higher ERs. While the majority of researchers had observed a similar pattern, Zainal et al. (2002) reported a decreasing trend of $\mathrm{N}_{2}$ with an increase in $\mathrm{ER}$, which is not quite possible. Water in the product gas also increases with an increase in ER for the ascendancy of the oxidation reaction of $\mathrm{H}_{2}$ at higher ERs. The $\mathrm{H}_{2} \mathrm{O}$ and $\mathrm{N}_{2}$ mix predicted by the model correlates well with the experimental values.

\section{Effect of Temperature on Molar Concentration}

Jayah et al. (2003) observed that a lower temperature reduces the reaction rate and thereby the conversion efficiency. Altafini et al. (2003) stated that equilibrium models are especially good at high temperatures where the reaction temperatures are above $1500 \mathrm{~K}$. The temperatures generally assumed for equilibrium modeling by different researchers were not coherent and were predominantly modeled between $800-1000 \mathrm{~K}$. Moreover the zone of the gasifier having this temperature was also not reported. Prins et al. (2006) remarked that for fluidized bed gasifiers, the average bed temperature can be used as the process temperature, whereas for downdraft gasifiers, the outlet temperature at the throat exit should be used. The temperature measured in the throat zone [T4] of the gasifier, using charred CNS, was about $1100^{\circ} \mathrm{C}$. Dogru et al. (2002) reported a throat temperature of $1015^{\circ} \mathrm{C}$ using hazelnut shells.

However keeping in mind the veracity of other work in the literature, the model was framed for a wide range of temperatures from $800 \mathrm{~K}$ to $1500 \mathrm{~K}$ and compared with the experimental results obtained at $1373 \mathrm{~K}$ (Figs 12 to 16). It should be noted that the deviation in gas composition within the temperature range selected was not very significant. Both exothermic and endothermic reactions occurred in the gasification system. Based on Le Chatelier's principle, it is understood that higher reaction temperatures favor the reactants in exothermic reactions while they favor the products in endothermic reactions. Methane formed in the gasifier at high temperatures underwent endothermic reactions with the already formed water vapor and was converted into $\mathrm{CO}, \mathrm{CO}_{2}$ and $\mathrm{H}_{2}$. Hence the yield of $\mathrm{CH}_{4}$ decreased at higher temperatures.

$$
\begin{aligned}
& \mathrm{CH}_{4}+\mathrm{H}_{2} \mathrm{O}=\mathrm{CO}+3 \mathrm{H}_{2} \\
& \mathrm{CH}_{4}+2 \mathrm{H}_{2} \mathrm{O}=\mathrm{CO}_{2}+4 \mathrm{H}_{2}
\end{aligned}
$$

The yield of $\mathrm{H}_{2}$ in the above reactions is three to four times that of formation of $\mathrm{CO}$ or $\mathrm{CO}_{2}$. Hence the increase in molar concentration of $\mathrm{H}_{2}$ is significantly higher than the increase observed in $\mathrm{CO}$ or $\mathrm{CO}_{2}$. Hence for gasification systems aimed towards generation of $\mathrm{H}_{2}$, maintaining of higher reaction temperature would be a remarkable advantage.

The endothermic reactions used the water vapor generated in the preliminary gasification process, as a result of which the yield of the $\mathrm{N}_{2}+\mathrm{H}_{2} \mathrm{O}$ mix was lower at higher temperatures. Since $\mathrm{N}_{2}$ forms the majority of the mix, the dip caused by reduction in moisture was almost insignificant. Precisely, it could be inferred that the cause for the drop in methane at higher temperatures and the increase in $\mathrm{CO}$ and $\mathrm{H}_{2}$ was due to the utilization of methane in endothermic reactions (rather a reforming process indeed). The trend obtained matches well with the style established by other researchers for other fuels (Turn et al., 1998; Luiz \& Silvio, 2007; Schuster et al., 2001; Philippe and Raphael, 2002; Yang, 2005; Sergrapagna \& Ajmal, 1997; Natarajan et al., 1988; Hos and Groeneveld, 1987). 


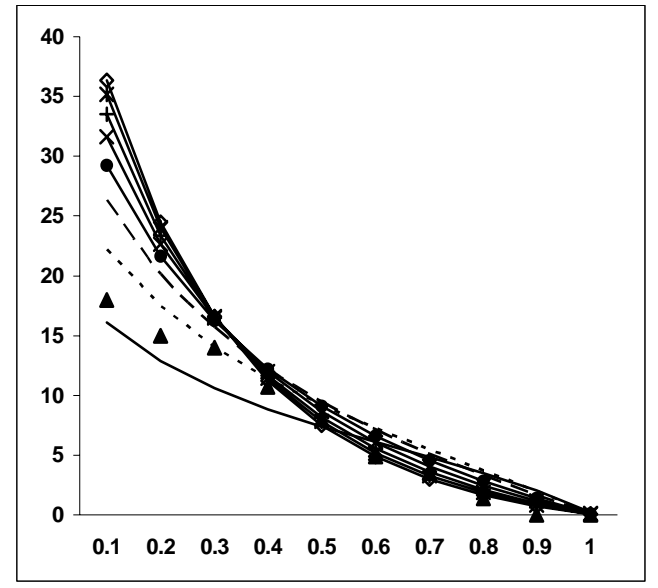

Figure 12: Yield of $\mathrm{H}_{2}$ at different bed $\mathrm{T}$ vs ER

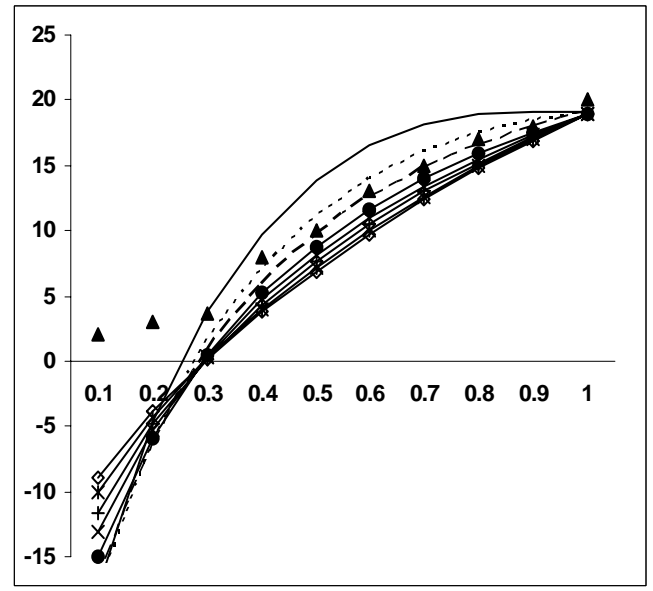

Figure 14: Yield of $\mathrm{CO}_{2}$ at different bed $\mathrm{T}$ vs ER

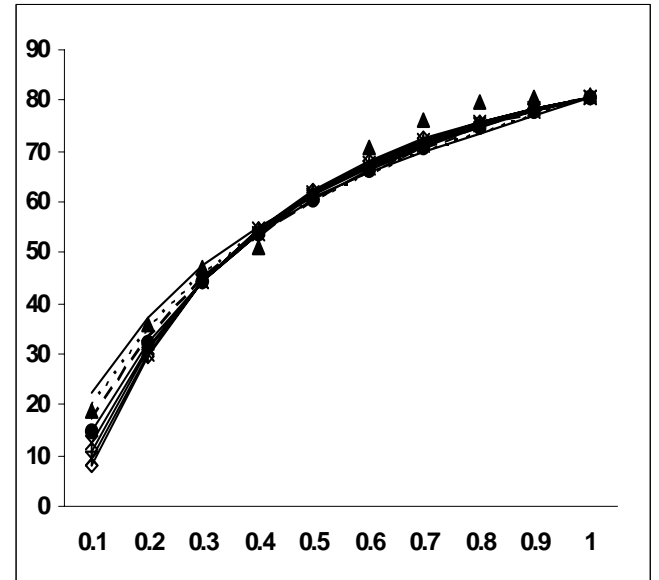

Figure 16: Yield of $\mathrm{N}_{2}+\mathrm{H}_{2} \mathrm{O}$ at different bed $\mathrm{T}$ vs ER

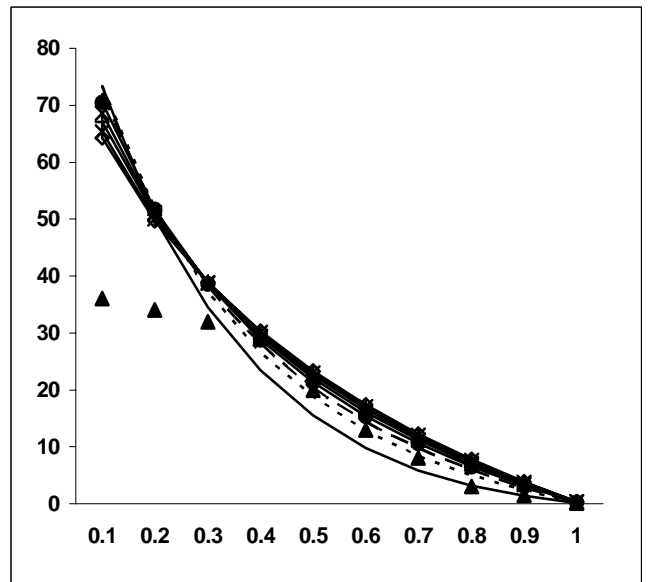

Figure 13: Yield of $\mathrm{CO}$ at different bed $\mathrm{T}$ vs ER

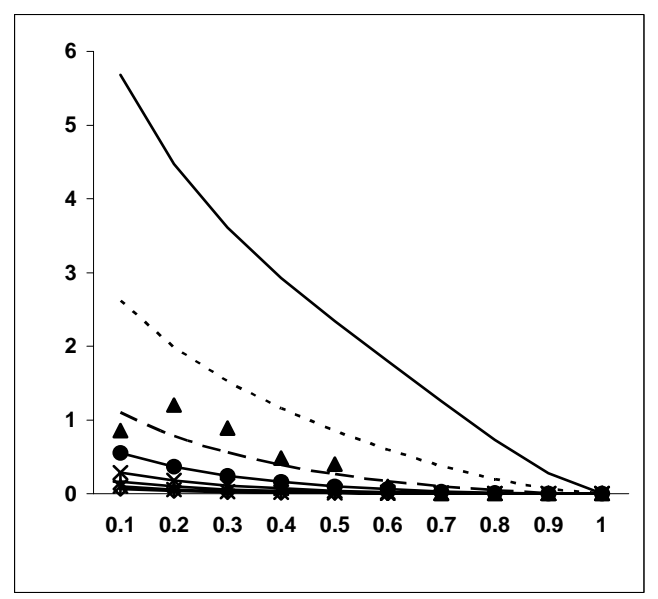

Figure 15: Yield of $\mathrm{CH}_{4}$ at different bed $\mathrm{T}$ vs ER

\section{Legends indicating temperatures}

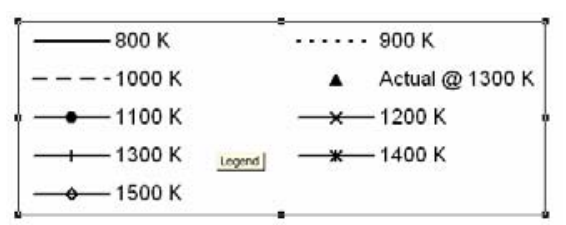


Effect of Moisture on Molar Concentration

Moisture content is one of the most significant properties of any biomass that are known to affect the gasification process. Hos and Groeneveld (1987) detailed the effect of moisture content of the feed material on the composition of the product gas. Bridgewater et al. (1986) cited that moisture constraints for any gasifier fuel are dependent on type of gasifier used. Higher values are possible in updraft systems, but the upper limit acceptable for a downdraft reactor is generally considered to be around $40 \%$ on a dry basis. Reed and Das (1988) specified that moisture content of feedstock should be below $33 \%$ (d.b.) for generating a burnable, good quality gas, while moisture contents higher than $67 \%$ (d.b.) make the product gas too lean for ignition. McKendry (2002) inferred that moisture content above about $30 \%$ makes ignition difficult and reduces the $\mathrm{CV}$ of the product gas due to the need to evaporate the additional moisture before combustion/gasification can occur. With this background, the present model was analyzed for the impact of moisture content on gas composition and the results were compared with the experimental values. Moisture content in a biomass could be either intrinsic (inherent) or extrinsic (influenced by weather/handling). The moisture in the producer gas is an amalgamation of the moisture sourced from substoichiometric air (relative humidity), water vapor formed due to oxidation of hydrogen in fuel and the intrinsic and extrinsic moisture associated with fuel. Among these contributing factors, the first two absorb only the sensible form of heat for superheating the moisture, while the last component absorbs sensible, latent and superheat for converting the moisture into a

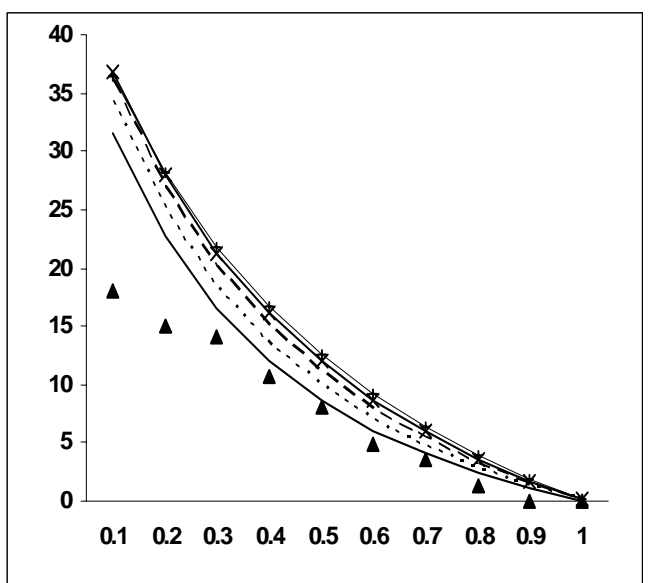

Figure 17: Molar \% of $\mathrm{H}_{2}$ with varied moisture vs ER superheated vapor form. The higher the fuel moisture content, the higher is the heat absorbed by the moisture, paving the way for a reduced reaction temperature and associated incomplete cracking of the hydrocarbons released from the pyrolysis zone.

Increased levels of moisture and the presence of $\mathrm{CO}$ at lower ERs produce more $\mathrm{H}_{2}$ and $\mathrm{CO}_{2}$ by the water gas shift reaction [Eq. 6]. The increased $\mathrm{H}_{2}$ content of the gas produces more $\mathrm{CH}_{4}$ by direct hydrogenation. Pellegrini and Oliveira Jr. (2007) inferred that though more $\mathrm{H}_{2}$ is formed with increased moisture, in order to maintain the process, more energy must be supplied, so exothermic reactions are favored, which promotes $\mathrm{CO}_{2}$ formation. The gain in $\mathrm{H}_{2}$ and $\mathrm{CH}_{4}$ of the product gas does not however compensate for the loss of energy due to the reduced $\mathrm{CO}$ content of the gas and therefore gives a product gas with a lower CV (McKendry, 2002). Similar results on the effect of moisture content have also been reported for conventional gasifiers (Bhattacharya et al., 1999; Parikh, 1985; Walawender et al., 1987). The model revealed similar trends for CNSC and the experimental values were observed to follow suit predicted by the model (Figs 17-21).

\section{Consolidation}

A comparison of the equilibrium modeling results vs the experimental values obtained upon gasification of CNSC is presented in Fig 22. The deviation observed is very minimal on the ER applicable to gasification, i.e., 0.15 to 0.4 for all constituents except $\mathrm{CO}_{2}$. However the experimental values of $\mathrm{CO}_{2}$ can be observed to match the modeled outputs well at ER $>0.3$.

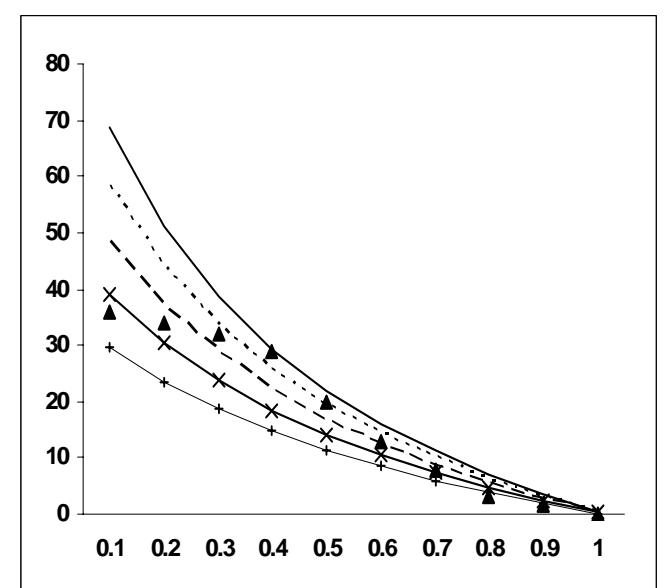

Figure 18: Molar \% of $\mathrm{CO}$ with varied moisture vs ER 

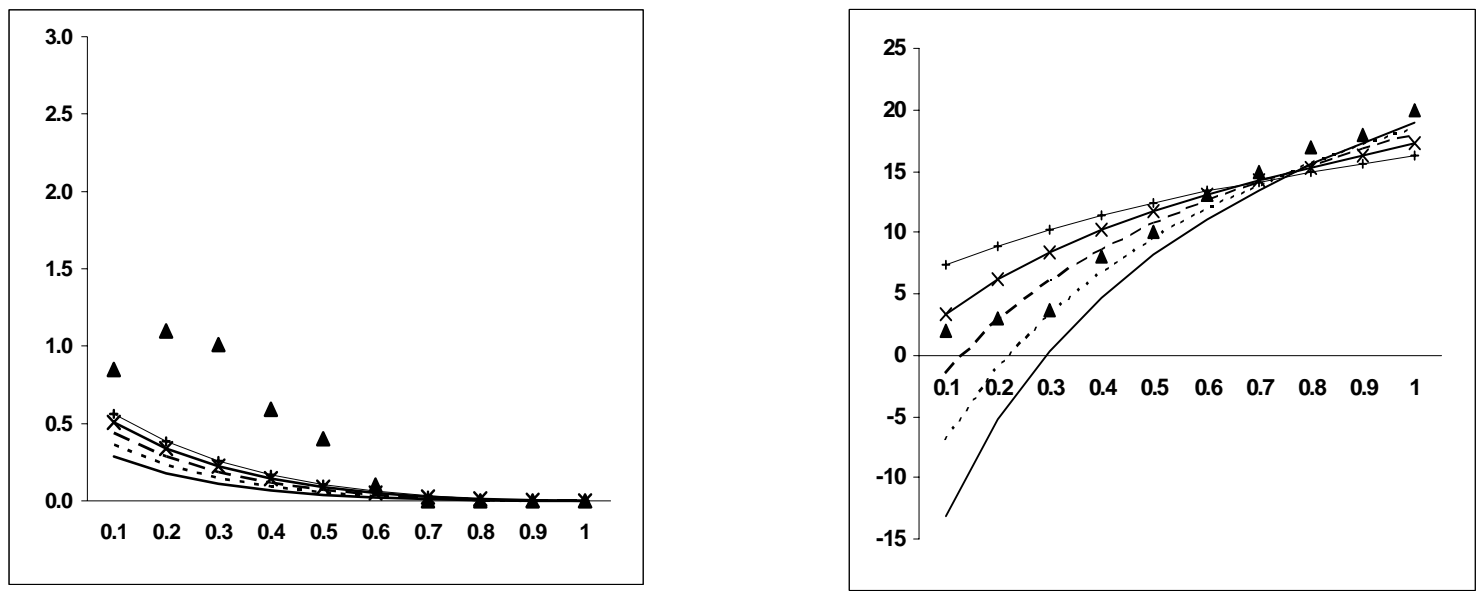

Figure 19: Molar \% of $\mathrm{CH}_{4}$ with varied moisture vs $\mathrm{ER}$ Figure 20: Molar $\%$ of $\mathrm{CO}_{2}$ with varied moisture vs ER

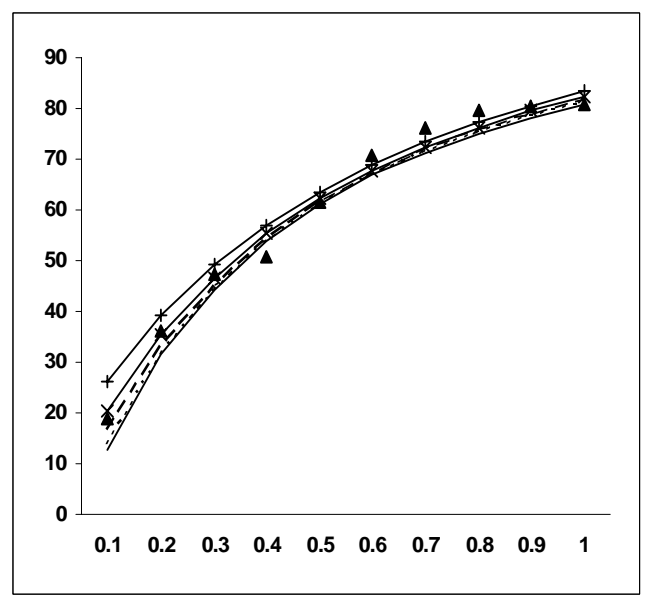

Effect of moisture on gas composition Legends indicate \% Moisture Content

Figure 21: Molar \% of $\mathrm{N}_{2}+\mathrm{H}_{2} \mathrm{O}$

with varied moisture vs ER
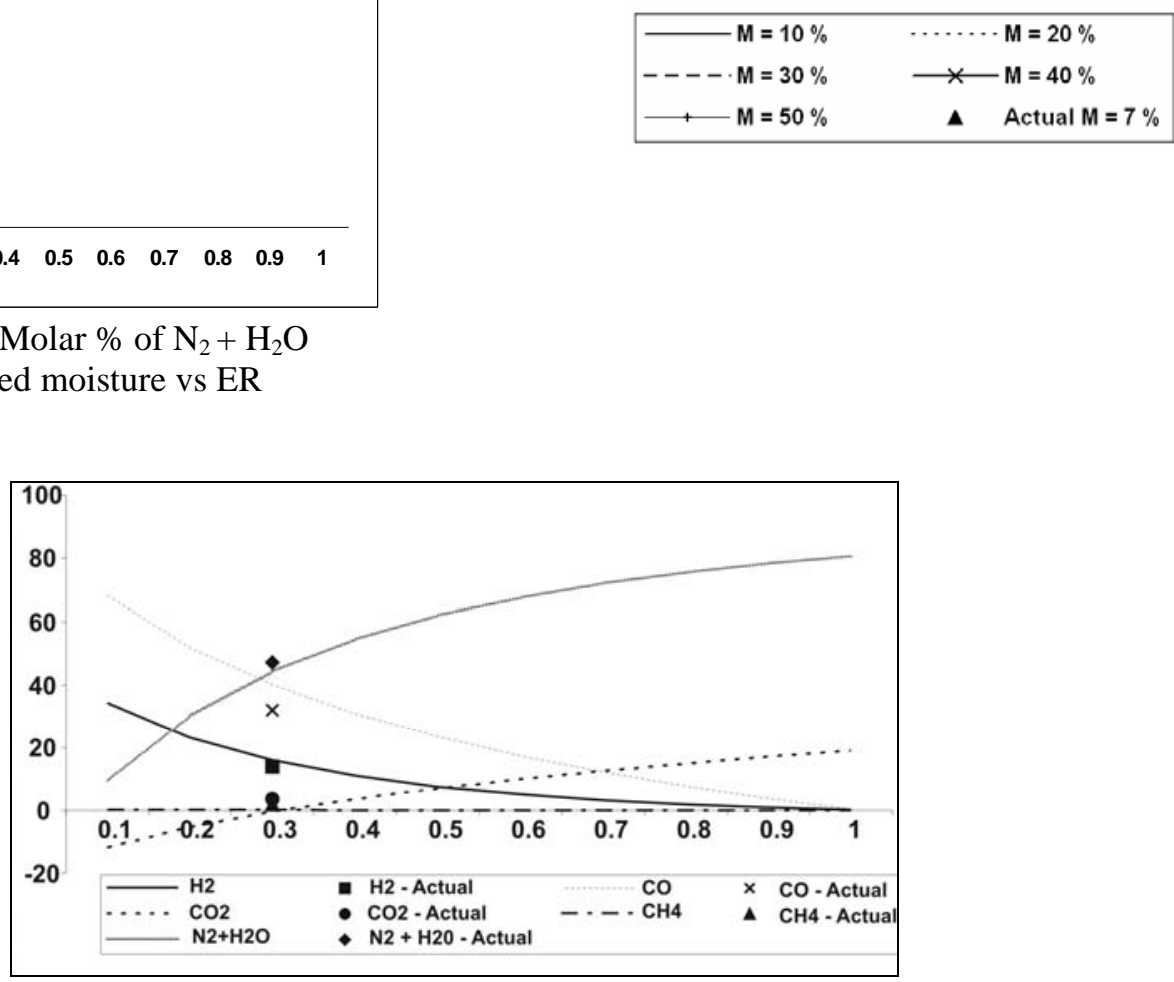

Figure 22: Molar concentration of producer gas vs ER 


\section{CONCLUSIONS}

- The concept of equilibrium modeling applies well for prediction of the effect of ER, MC and RT in gasification of CNSC.

- ER is observed to have a large impact on the composition of the producer gas. The model predicts well the trend for $\mathrm{H}_{2}, \mathrm{CO}, \mathrm{N}_{2}$ and $\mathrm{H}_{2} \mathrm{O}$. For $\mathrm{CO}_{2}$, the model depicts negative values, possibly, owing to the effect of the carbon-hydrogen ratio, which had been proven by application of the same model for gasification of casuarina wood.

- The contribution of reaction temperature is significant for hydrogen yield. The composition of $\mathrm{H}_{2}$ at an ER of 0.3 maintained at a RT of $800 \mathrm{~K}$ is $10.5 \%$, while at $900 \mathrm{~K}$ it is $14 \%$, an increase of 33 $\%$. However at the same ER, the yield is not so pronounced between 1100 and $1500 \mathrm{~K}$. Higher temperatures favor the formation of $\mathrm{CO}$ and minimize the yield of $\mathrm{CH}_{4}$. For temperatures higher than $1200 \mathrm{~K}, \mathrm{CH}_{4}$ generation is practically nil.

- The model does predict the effect of MC in a relevant manner. The $\mathrm{CH}_{4}$ content increases with moisture content. At an ER of 0.3 and with a fixed RT of $1373 \mathrm{~K}$, the yield of $\mathrm{CH}_{4}$ is $0.14 \%$ at $10 \%$ moisture, while it is $0.25 \%$ at $50 \%$ moisture, an 80 $\%$ increase.

- The model predicts an unrealistic gas composition at ERs less than 0.15 , due to pyrolysis, for all constituents of producer gas. For ER pertaining to gasification and beyond that, the model's prediction is coherent with experimental values.

\section{ACKNOWLEDGEMENTS}

The financial support provided by the Ministry of New \& Renewable Energy, Government of India, New Delhi is thankfully acknowledged. The support rendered by Mr. M. Sundaresan, Fitchner Consulting Engineers, Chennai; Mr. S. Kasiraman, GEBangalore; Mr. G. Vidyasagar and Mr. G. Muthukumar are appreciated.

\section{NOMENCLATURE}

$\Delta \mathrm{G}^{\circ} \quad$ Standard Gibbs function of formation

$\Delta \mathrm{A}, \Delta \mathrm{B}, \Delta \mathrm{C}$ Coefficients for determining

and $\Delta \mathrm{D} \quad$ specific heat

$\Delta \mathrm{H}^{\circ} \quad$ Heat of formation

$\begin{array}{llr}\mathrm{A}, \mathrm{B}, \mathrm{C} \text { and } & \text { Constants for the properties } \\ \mathrm{D} & \text { of the gases } & (-) \\ \mathrm{CNS} & \text { Cashew nut shell } & (-) \\ \mathrm{CNSC} & \text { Cashew nut shell char } & (-) \\ \mathrm{CNSL} & \text { Cashew nut shell liquid } & (-) \\ \mathrm{C}_{\mathrm{p}} & \text { Specific heat } & (-) \\ \mathrm{C}_{\mathrm{p}(\mathrm{am})} & \text { Specific heat at arithmetic } & (-) \\ & \text { mean temperature } \\ \mathrm{ER} & \text { Equivalence ratio } & (-) \\ \mathrm{HHV} & \text { Higher heating value } & \mathrm{kJ} / \mathrm{kg} \\ \mathrm{I} & \text { Constant of integration } \\ \mathrm{J} & \text { Constant } & (-) \\ \mathrm{K}_{1} \& \mathrm{~K}_{2} & \text { Equilibrium constants } \\ \mathrm{m} & \text { Amount of oxygen per kmol } & (-) \\ & \text { of wood } & (-) \\ \mathrm{MC} & \text { Moisture content per mol of } & (-) \\ & \text { wood } & (-) \\ \mathrm{MC} & \text { Moisture content } & (-) \\ \mathrm{R} & \text { Universal gas constant }(\mathrm{J} & (-) \\ & \text { /mol k) } & (-) \\ \mathrm{RT} & \text { Reaction temperature } \\ \mathrm{T}_{1} & \text { Reference temperature } \\ \mathrm{T}_{2} & \text { Reaction temperature } \\ \mathrm{T}_{\mathrm{am}} & \text { Arithmetic mean } \\ & \text { temperature } & (-) \\ \mathrm{w} & \text { Amount of water per kmol } & (-) \\ & \text { of wood } & (-) \\ \mathrm{x}_{1}, \mathrm{x}_{2}, \mathrm{x}_{3}, \mathrm{x}_{4} \text { Coefficients of constituents } \\ \mathrm{and} \mathrm{x}_{5} & \text { of the producer gas } & (-) \\ & & (-) \\ & \end{array}$

\section{REFERENCES}

Agricultural statistics at a glance - India, Agricultural Statistics Division, Ministry of Agriculture, Government of India p. 100 (2003).

Bhattacharya, S. C., Md. Mizanur Rahman Siddique A. H., Hoang-Luong Pham, A study on wood gasification for low-tar gas production, Energy 24, p. 285-296 (1999).

Bridgewater, A. V., Double, J. M. and Earp, D. M., Technical and market assessment of biomass gasification in the United Kingdom, ETSU Report, UKAEA, Harwell, UK (1986).

Carlos R. Altafini, Paulo R. Wander and Ronaldo M. Barreto, Prediction of the working parameters of a wood waste gasifier through an equilibrium model, J. Energy Conversion and Management, 44, p. 2763 - 2777 (2003).

Desrosiers R. Thermodynamics of gas-char reactions. In: Reed TB, editor. Biomass gasification Principles and technology. New Jersey: Noyes Data Corporation, p. 119 (1981). 
Dogru M., Howarth, C. R., Akay G., Keskinler B. and Malik, A. A., Gasification of hazelnut shells in a downdraft Gasifier, Energy, 27, p. 415-427 (2002)

Fock, F. and Thomsen, K. P. B, Modelling a biomass gasification system by means of EES, The Scandinavian Simulation Society, Technical University of Denmark (2000).

Hos, J. J and Groeneveld, M. J., Biomass Gasification. In: Hall DO, Overend RP, editors. Biomass regenerable energy.chichester: Wiley (1987).

http://dacnet.nic.in/cashewcocoa/cashew.htm.

http://en.wikipedia.org/wiki/Cashew.

http://www.cashewindia.org.

Jigisha Parikh, Channiwala, S. A. and Ghosal, G. K., A correlation for calculating $\mathrm{HHV}$ from proximate analysis of solid fuels, Fuel, 84, p. 487-494 (2005).

Luiz Felipe Pellegrini, Silvio de Oliveira Jr., Exergy analysis of sugarcane bagasse gasification, $\mathrm{J}$. Energy, 32, p. 314-327 (2007).

Lv, P. M., Xiong, Z. H., Chang J., Wu, C. Z., Chen Y. and Zhu J. X., An experimental study on biomass air-steam gasification in a fluidized bed, Bioresource Technology, 95, p. 95-101(2004).

Mansaray, K. G., Ghaly, A. E., Al-taweel, A. M., Hamdullahpur F. and Ugursal, V.I., Air gasification of rice husk in a dual distributor type fluidized bed gasifier, Biomass and Bioenergy, 17, p. 315-332 (1999).

Mark J. Prins, Krzysztof J. Ptasinski and Frans J. J. G. Janssen., From coal to biomass gasification: Comparison of thermodynamic efficiency, Energy doi: 10.1016/ j.energy.2006.07.017 (2006).

Natarajan E., Nordin A. and Rao, A. N., Overview of Combustion and Gasification of Rice Husk in Fluidized Bed Reactors, Biomass and Bioenergy, Vol. 14, Nos. 5/6, p. 533-546, (1988).

Parikh P. P, State of art report on gasification of biomass, Report of DNES project, IIT - Bombay (1985).

Peter McKendry, Energy production from biomass, part 3: Gasification Technologies, Bioresource Technology, 83, p. 55-63 (2002).

Philippe Mathieu, Raphael Dubuisson, Performance analysis of a biomass gasifier, Energy Conversion and Management, 43, p. 1291-1299 (2002).

Piyali Das, Anuradda Ganesh, Bio-oil from pyrolysis of cashew nut shell - a near fuel, Biomass and Bioenergy, 25, p. 113 - 117 (2003).
R \& D report, Decentralized power generation through carbonization \& gasification of cashew shells, IES, Anna University, May 2006.

Reed, T. B. and Das A., Handbook of biomass downdraft gasifier engine system. Golden, CO: SERI (1988).

Robert, H. P. and Don, W. G., Perry's chemical engineer's handbook, Sixth edition, New York: McGraw Hill (1984).

Ruggiero M. and Manfrida G., An equilibrium model for biomass gasification processes. Renewable Energy, 16, p. 1106-1109 (1999).

Schuster G., Loffler G., Weigl K. and Hofbauer H., Biomass steam gasification - An extensive parametric modeling study, Bioresource Technology, 77 (2001).

Sergrapagna and Ajmal Latif, Steam Gasification of Almond Shells in a Fluidized Bed Reactor: The influence of Temperature and Particle size on Product Yield and Distribution, Biomass and Bioenergy, Vol. 12, No. 4, p. 281-288 (1997).

Stull D. R. and Prophet H., JANAF Thermochemical Tables, NSRDA - NBS 37 (1971).

T. H. Jayah, Lu Aye, R. J. Fuller and D. F. Stewart, Computer simulation of a downdraft wood gasifier for tea drying, Biomass and Bioenergy, 25, p. 459 - 469 (2003).

Turn S., Kinoshita C., Zhang Z., Ishimura D. and Zhou J., An Experimental Investigation of Hydrogen Production from Biomass Gasification, Int. J. Hydrogen Energy, Vol. 23, No. 8, p. 641648 (1998).

Von Fredersdorff, C. G., Elliot, M. A., Chemistry of Coal Utilization, 3, H.H. Lowry, Ed., Wiley Publisher, New York (1963).

Walawender, W.P., Chern S.M., Fan LT. In: Klass DL, editor, Energy from biomass and wastes XI, Chicago: Institute of Gas Technology (1987).

Yang, Y. B., Effect of fuel properties on biomass combustion. Part II. Modelling Approach Identification of the controlling factors, Fuel, 84, p. 2116-2130 (2005).

Zainal, Z. A., Ali Rifau, Quadir, G. A. and Seetharamu, K. N., Experimental investigation of a downdraft biomass gasifier, Biomass and Bioenergy, 23, p. 283 - 289 (2002).

Zainal, Z. A., R Ali, Lean, C. H. and Seetharamu, K. N., Prediction of performance of a downdraft gasifier using equilibrium modeling of different biomass materials, Energy Conversion and Management, 42, p. 1499-1515 (2001). 